\title{
Spiritualitas Menurut Yohanes Calvin dan Implikasinya bagi Pendidikan Warga Gereja di Era New Normal
}

\author{
Agustina Pasang \\ STT Glow, Jakarta \\ thina340@gmail.com
}

\begin{abstract}
One of the spiritualities that is important to learn and understand is spirituality according to John Calvin, which emphasizes the importance of the principle regarding the relationship between humans and God. Deeper recognition gives an indication that a person's relationship with God is getting closer and closer to God, which will have an impact on spiritual growth. However, the spiritual understanding that is widely discussed today does not always originate from the existence of God but also from the potential of the human self. The Purpose of this paper is to understand spirituality according to Calvin, so that it can be a reference for the education of church members in the new normal era. This research uses descriptive research method with a literature review approach and field data collectionate the Indonesian Evangelical Mission Alliance Church in Balikpapan. Spirituality according to Calvin, if properly understood can help church members to have a correct understanding of knowing God and realizing the importance of spiritual growth and can find the strength to continue to grow in a stronger spiritual life that is expressed in the attitude of each individual's life.
\end{abstract}

Keywords: education church members, new normal, spirituality

Abstrak: Salah satu spiritualitas yang penting untuk dipelajari dan dipahami adalah spiritualitas menurut Yohanes Calvin, menegaskan pentingnya relasi antara manusia dengan Allah. Pengenalan yang semakin dalam memberi indikasi semakin erat dan intimnya relasi seseorang dengan Allah yang berdampak pada pertumbuhan spiritualitas. Namun pemahaman spiritual yang ramai dibicarakan saat ini tidak selalu bertolak dari keberadaan Allah tetapi juga dari potensi diri manusia. Tujuan dari penulisan ini adalah untuk memahami spiritualitas menurut Calvin, supaya dapat menjadi acuan bagi pendidikan warga gereja di era new normal. Adapun penelitian ini menggunakan metode penelitian deskriptif dengan pendekatan kajian literatur dan pengumpulan data lapangan di Gereja Persekutuan Misi Injili Indonesia (GPMII) Balikpapan. Spiritualitas menurut Calvin, jika dipahami secara benar dapat menolong warga gereja untuk memiliki pemahaman yang benar mengenai pengenalan akan Allah serta menyadari pentingnya pertumbuhan spiritualitas dan dapat menemukan kekuatan untuk terus bertumbuh dalam kehidupan spiritualitas yang lebih kokoh yang dinyatakan dalam sikap hidup tiap hari

Kata kunci: new normal, pendidikan warga gereja, spiritualitas 


\begin{tabular}{llll}
\hline Article History : & Received: 28-10-2020 & Revised: 28-12-2020 & Accepted: 28-12-2020
\end{tabular}

\section{Pendahuluan}

Semua agama mengajarkan hal-hal yang bersifat spiritual kepada para pengikutnya sekalipun itu dilakukan dengan konsep dan praktek agama yang berbeda. Beberapa ilmuwan, filsuf dan teolog kontemporer berpendapat bahwa bumi bukan hanya merupakan konteks untuk mengalami kebenaran melalui berbagai cara, tetapi juga merupakan suatu kisah bersama dimana setiap agama mengalami pengalaman religius yang berbeda. ${ }^{1}$ Ini mengindikasikan bahwa semua agama mengklaim diri telah mengalami pengalaman-pengalaman religius dan mempunyai norma-norma yang mengatur kehidupan. Refleksi perjalanan keagamaan seringkali disusun menjadi kerangka kerja yang menyatu yang membentuk pengalaman keagamaan sehingga menghasilkan jenis spiritualitas yang berbeda-beda. ${ }^{2}$ Menurut agama Islam, Allah adalah sumber spiritualitas berdasarkan tauhid/ajaran yang menegaskan bahwa Tuhan adalah asal-usul dan tujuan hidup manusia, termasuk peradaban dan ilmu pengetahuannya. Dengan tauhid kaum muslimin diharapkan mampu menawarkan penyelesaian atau masalah kehampaan spiritual. Dengan menjadikan Tuhan sebagai tujuan akhirnya, manusia akan terbebas dari kehampaan spiritual. ${ }^{3}$ Jelas bahwa dalam kehidupan spiritual dibutuhkan hubungan manusia dengan Allah.

Alkitab menjelaskan bahwa manusia adalah mahkluk spiritual (Kej 2:7) dan mulia karena diciptakan menurut gambar dan rupa Allah (Kej 1:26) sehingga berbeda dengan semua ciptaan lain dan menjadi yang tertinggi sebagai mahkota ciptaan Allah. ${ }^{4}$ Manusia sebagai gambar dan rupa Allah memiliki keistimewaan karena mirip dengan Allah dan memiliki potensi untuk bisa memancarkan kemiripan dengan Allah. ${ }^{5}$ Ketika manusia jatuh dalam dosa semua potensi yang bisa memancarkan kemiripan dengan Allah tidak dapat lagi digunakan untuk memuliakan Allah karena telah dirusak oleh dosa dan menyebabkan manusia terpisah dari Allah secara rohani. ${ }^{6}$ Sehingga tidak mungkin ada kesalehan sejati yang masih tertinggal dalam diri manusia. Melalui Kristus, Allah mendamaikan diri-Nya dengan manusia dalam proses kelahiran baru yang dikerjakan oleh Roh Kudus. Pribadi dan karya Kristus menjadi model bagi pertumbuhan spiritualitas itu sendiri. ${ }^{7}$ Namun kenyataannya pemahaman spiritual yang ramai

\footnotetext{
1 Paul F. Knitter, Satu Bumi Banyak Agama (Jakarta: BPK Gunung Mulia, 2003), 172.

${ }^{2}$ Simon Chan, Spiritual Teologi (Yogyakarta: ANDI, 2002), 14.

3 Nurcholis Madjid, "Kehampaan Spiritual Masyarakat Modern," dalam Agama Dan Kegalauan Masyarakat Modern (Jakarta: Mediacita, 2000), 101-102.

${ }^{4}$ Louis Berkhof, Teologia Sistematika 2: Doktrin Manusia (Jakarta: LRII, 1995),56.

${ }^{5}$ Stephen Tong, Peta Dan Teladan Allah (Surabaya: Momentum, 1990), 49.

${ }^{6}$ Loraine Boettner, Iman Reformed (Surabaya: Momentum, 2000), 17.

${ }^{7}$ Ronald S. Wallace, Calvin's Doctrine of the Christian Life (Geneva: Divinity School Press, 1982), 41.
} 
dibicarakan tidak selalu bertitik tolak dari keberadaan Allah yang menjadi sumber dari segala yang hidup, tetapi juga pada potensi diri manusia yang pada awalnya memang dikenal sebagai mahkluk spiritual yang dipromosikan sebagai bentuk kecerdasan tertinggi yang bertitik tolak pada potensi diri manusia. Jika tidak diwaspadai, ini dapat membawa seseorang untuk berpikir bahwa manusia dapat mengembangkan potensi dirinya dan mampu melakukan segala sesuatu tanpa pertolongan Allah. Akibatnya pengenalan akan Allah dan pentingnya relasi dengan Allah tidak lagi menjadi prinsip karena manusia lebih fokus kepada kemampuan atau potensi diri yang dimiliki.

Pada era new normal, kehidupan orang percaya juga mengalami banyak tantangan akibat pandemi Covid 19. Kehilangan pekerjaan sementara kebutuhan ekonomi tetap harus dipenuhi, perasaan takut/kuatir tertular Covid 19, meningkatnya kasus kejahatan dan sebagainya tidak jarang membuat orang percaya mulai meragukan bahkan mempertanyakan benarkah Tuhan menolong? Tuhan memelihara? Dan berbagai pertanyaan lain yang bisa membuat seseorang mulai malas berdoa, malas membaca Alkitab, tidak ada kerinduan bersekutu serta kurangnya pemahaman akan pentingnya kehidupan spiritualitas. Dengan demikian di era new normal ini, kehidupan spiritualitas mutlak diperlukan untuk membuat orang percaya memiliki keyakinan/ keteguhan akan mampu bertahan dalam berbagai keadaaan.

\section{Metode Penelitian}

Peneliti menggunakan penelitian deskriptif yakni metode yang dipakai untuk meneliti sekelompok manusia, suatu objek, suatu kondisi, sistem pemikiran ataupun suatu kelas peristiwa pada masa sekarang. ${ }^{8}$ Nazir juga mengutip pandangan Whitney bahwa penelitian deskriptif adalah metode pencarian fakta dengan interpretasi yang tepat. ${ }^{9}$ Metode ini mendeskripsikan data dari berbagai literatur dan hasil penelitian sehubungan dengan topik. Dalam hal ini penulis menggunakan metode penulisan deskriptif dengan pendekatan kajian literatur dan pengumpulan data lapangan melalui penyebaran angket. Penelitian dilaksanakan di Gereja Persekutuan Misi Injili Indonesia (GPMII) di Balikpapan, yang bercorak Calvinis.

\section{Hasil dan Pembahasan}

\section{Latar Belakang Pemikiran Teologia Yohanes Calvin}

Pemikiran theologia Calvin sangat dipengaruhi oleh bapa-bapa gereja diantaranya Agustinus dan Martin Luther. Ketiganya hidup dalam zaman yang berbeda, Agustinus lahir 13 Nopember 354 di Afrika Utara, sedangkan Calvin lahir 1509 ketika Luther sudah memberikan kuliah di Universitas Effrurt. ${ }^{10}$ Pola pikir Agustinus sangat besar terhadap

\footnotetext{
${ }^{8}$ Mohammad Nazir, Metode Penelitian (Jakarta: Ghalia Indonesia, 1988), 63.

9 Ibid.

${ }^{10}$ Christian de Jonge, Apa Itu Calvinisme? (Jakarta: PT BPK Gunung Mulia, 2001), 46.
} 
Calvin. Demikian juga dengan Luther sekalipun Calvin tidak pernah bertemu langsung dengannya. Ia hanya membaca tulisan-tulisan Luther yang dibacanya sejak 1528.

\section{Tema Sentral Teologia Yohanes Calvin dalam Institutio}

Allah sebagai Pencipta

Calvin menjelaskan bahwa Allah adalah Pencipta satu-satunya dari segala sesuatu sehingga ciptaan memiliki keterikatan dan kebergantungan yang mutlak kepada Allah. ${ }^{11}$ Oleh karena itu, manusia sebagai ciptaan harus tunduk dan menghambakan diri serta menyadari bahwa hidupnya bergantung kepada Allah. ${ }^{12}$ Namun manusia tidak dapat memahami hakekat Allah. ${ }^{13}$ Karena ketidakmampuan inilah Allah menyatakan diri melalui seluruh ciptaanNya. Di sisi lain dosa membuat manusia tidak mampu menyelamatkan diri namun Allah berinisiatif mencari dan memberikan janji penebusan melalui Yesus Kristus. Melalui ketaatan-Nya, Kristus menghapus dosa orang percaya. KematianNya mengganti hukuman karena dosa, tetapi bukan berarti bahwa penebusan yang dikerjakan Kristus itu terbatas melainkan penerapan penebusan keselamatan hanya terbatas pada orang pilihan. ${ }^{14}$ Penebusan ini menjamin keselamatan dan iman kepada Kristus memastikan keselamatan tersebut. ${ }^{15}$ Roh Kudus mengerjakan iman dalam diri orang percaya melalui proses kelahiran baru. ${ }^{16}$

\section{Allah sebagai Penyelamat}

Roh Kudus memungkinkan orang percaya bersatu dengan Kristus. Calvin menuliskan: "...the Holy Spirit is the bond by which Christ effectually unites us to himself," Roh Kudus adalah pengikat antara orang percaya dengan Kristus yang bekerja dalam hati orang berdosa dan menerapkan keselamatan yang sudah dikerjakan oleh Kristus di kayu salib. Iman adalah pekerjaan Roh Kudus dan tidak pernah lepas dari pengetahuan yang diperoleh dari Firman. Iman adalah pengetahuan akan kehendak Allah yang diperoleh dari FirmanNya. ${ }^{17}$ Pertobatan berarti membalikkan kehidupan kepada Allah dengan mematikan keinginan daging atau manusia lama.

\section{Allah sebagai Kepala Gereja}

Gereja adalah sarana yang diberikan Allah kepada orang percaya yang lemah untuk membina dan memelihara mereka dalam iman. Fungsi gereja tidak dapat diremehkan

11 John T. McNeill, Calvin: Institutes of the Christian Religion (Philadelphia: The Westminster Press, 1960), 39-41.

12 Yohanes Calvin, Institutio: Pengajaran Agama Kristen, ed. Arifin dan Th. van den End Winarsih, J.S. Aritonang (Jakarta: BPK Gunung Mulia, 2015), 9.

${ }^{13}$ Louis Berkhof, Teologi Sistematika 1: Doktrin Allah (Jakarta: LRII, 1993), 28-29.

14 Boettner, Iman Reformed, 151.

15 Stevri I. Lumintang, Theologia Dan Misiologia Reformed (Batu: Dept. Literatur YPPII, 2006), 199.

16 W.F. Dankbaar, Calvin, Djalan Hidup Dan Karjanya (Jakarta: BPK Gunung Mulia, 1967), 161-162.

17 McNeill, Calvin: Institutes of the Christian Religion, 538,549. 
sebab manusia tidak akan mampu memelihara diri sendiri dalam kebenaran iman. ${ }^{18}$ Menurut Calvin, gereja adalah persekutuan orang kudus yaitu persekutuan orang yang percaya dan disucikan di dalam Kristus dan yang disatukan dengan Dia sebagai standar Kepala mereka. ${ }^{19}$ Kristus adalah Kepala Gereja dan orang percaya sebagai tubuhNya.

\section{Hubungan Teologi Yohanes Calvin dengan Spiritualitas}

\section{Allah sebagai Pencipta dan Spiritualitas}

Pengenalan akan Allah bukan hanya suatu pengakuan yang sifatnya dipermukaan tetapi merupakan pengenalan tentang Allah dalam relasi pribadi denganNya, yang kemudian membawa kepada suatu sikap yang benar dalam relasi tersebut. ${ }^{20}$ Jadi bagi Calvin, keterlibatan Allah dalam relasi itu bukan hanya sebagai obyek pengenalan tetapi sebagai sumber yang mutlak dan yang terutama. Allah adalah pencipta satu-satunya dari segala sesuatu sehingga setiap ciptaan memiliki keterikatan dan kebergantungan mutlak pada Allah. Artinya kehidupan spiritualitas orang percaya tidak lepas dari Allah dalam karya penciptaanNya yang menjadi salah satu sarana untuk menyatakan diriNya supaya manusia dapat mengenal Allah dan mengagungkan kebesaran Allah dalam hidupnya.

\section{Allah sebagai Penebus dan Spiritualitas}

Dosa adalah kejahatan yang menghalangi dan memisahkan manusia dari kasih karunia Allah. Dalam kondisi inilah Allah menyatakan kasihNya melalui karya penebusan Kristus melalui kematian di kayu salib Allah menyediakan keselamatan bagi umat pilihan. ${ }^{21}$ Penebusan Kristus memungkinkan manusia untuk kembali memiliki hubungan yang intim dengan Allah. Jadi spiritualitas orang percaya tidak bisa dipisahkan dari karya penebusan Kristus.

\section{Allah sebagai Penyelamat dan Spiritualitas}

Pertobatan berarti membalikkan kehidupan kepada Allah dengan rasa takut yang tulus dan sungguh-sungguh dengan mematikan keinginan daging atau manusia lama. ${ }^{22}$ Kehidupan spiritualitas dalam diri orang percaya merupakan karya Roh Kudus, artinya kedaulatan Allah dalam karya penyelamatan yang dikerjakan Roh Kudus juga mempengaruhi kehidupan spiritualitas seseorang, yang memungkinkan dia memiliki hubungan erat dan intim dengan Allah. Roh Kudus bekerja memperbaharui pikiran dan kehendak manusia sehingga dibawa ke dalam persekutuan dengan Kristus dan dihidupkan kembali secara rohani.

\footnotetext{
18 Jonge, Apa Itu Calvinisme?, 98-99.

${ }^{19}$ Louis Berkhof, Teologi Sistematika 5" Doktrin Gereja (Jakarta: LRII, 1997), 22-23.

${ }^{20}$ Francois Wendel, Calvin Origin and Development of His Religious Thought (Michigan: Baker Book House, 1997), 152-153.

21 McNeill, Calvin: Institutes of the Christian Religion, 964-965.

22 Yohanes Calvin, Institutio: Pengajaran Agama Kristen, 116.
} 
Allah sebagai Kepala Gereja dan Spiritualitas

Pengudusan seseorang, pertumbuhan, pemeliharaan disiplin dalam kehidupan Kristennya dapat diperoleh dalam kehidupan gereja. ${ }^{23}$ Sehingga spiritualitas tidak terlepas dari gereja karena dipelihara berdasarkan hubungan dengan sesama anggota gereja yang adalah tubuh Kristus. ${ }^{24}$ Gereja menjadi tempat yang sentral dimana Kristus menyatakan diriNya. Calvin menekankan pentingnya kehidupan spiritualitas dalam gereja, dimana Allah adalah Kepala Gereja sekaligus menjadi sarana bagi orang percaya untuk memelihara iman sekaligus memelihara kehidupan spiritualitas.

\section{Spiritualitas menurut Calvin}

Calvin menghabiskan seumur hidupnya untuk memetakan suatu spiritualitas dimana Allah sebagai pusat dari pencarian spiritualitas. Tema itu paling mendominasi pemikiran Calvin. Ia menulis Institutes yang diberi sub judul: A Sum of Piety. Bagi Calvin kehidupan spiritual bukan hanya sebagai serangkaian pengalaman yang menggentarkan jiwa, tetapi sebagai satu kebiasaan hati. ${ }^{25}$ Kehidupan spiritualitas adalah relasi manusia dengan Allah yang dijelaskan dalam kaitannya dengan seluruh hikmat manusia yang tidak terpisahkan dari pengenalan akan Allah dan pengenalan akan diri sendiri. ${ }^{26}$

\section{Dasar Spiritualitas menurut Yohanes Calvin}

Dua prinsip yang berkenaan dengan relasi antara manusia dengan Allah. yakni pengenalan akan Allah dan pengenalan akan diri sendiri. ${ }^{27}$ Pengenalan tentang diri Allah dalam relasiNya dengan pribadi yang mengenalNya kemudian membawa pada suatu sikap yang benar dalam relasi tersebut. ${ }^{28}$ Tindakan Allah memulihkan spiritualitas juga nampak melalui Kitab Suci yang menjadi sarana tuk membawa manusia pada pengenalan akan Allah. Melalui Pribadi dan karya Kristus, melalui pekerjaan Roh Kudus dan melalui Kitab Suci sebagai wahyu Allah, membawa manusia pada pengenalan yang benar akan Allah. Wallace menegaskan hal yang penting bagi Calvin dalam konsepnya mengenai spiritualitas adalah bagaimana kehidupan Kristen diubahkan untuk menjadi serupa dengan Kristus, hidup berpadanan dengan Kristus, karena melalui Kristus didapatkan kesempurnaan rupa Allah Bapa. ${ }^{29}$ Dengan demikian dasar spiritualitas menurut Calvin adalah Allah yang menyatakan Dia adalah sumber dari spiritualitas itu

${ }^{23}$ Wallace, Calvin's Doctrine of the Christian Life, 195.

24 Joel R. Beeke, "Calvin on Piety," dalam The Cambridge Companion to John Calvin, ed. Donald K. McKim (Cambridge: University Press, 2004), 131.

${ }_{25}$ Mark Shaw, Sepuluh Pemikiran Besar Dari Sejarah Gereja (Surabaya: Momentum, 2003), 49-53

${ }^{26}$ McNeill, Calvin: Institutes of the Christian Religion, 37.

27 Ibid.

28 Wendel, Calvin Origin and Development of His Religious Thought, 150,152-153.

${ }^{29}$ Wallace, Calvin's Doctrine of the Christian Life, 107-108. 
sendiri. Spiritualitas adalah karya dan kasih karunia Allah yang diberikan kepada orang percaya.

\section{Aspek-aspek Spiritualitas menurut Yohanes Calvin}

Menyangkal Diri

Menyangkal diri berhubungan dengan kepemilikan diri sendiri bahwa manusia milik Allah Pencipta, Penebus dan Penyelamat, Calvin menulis:

We are not own: let not our reason nor our will, therefore, sway our plans and deeds. We are not our own: let us therefore not set it as our goal to seek what is expedient for us according to the flesh. We are not our own: in so far as we can, let us therefore forget ourselves and all that is ours. ${ }^{30}$

Orang percaya adalah milik Allah karena itu harus tunduk pada Allah, mengabdi dan melakukan segala sesuatu berdasarkan kehendak Allah, menjadikan Allah sebagai satusatunya tujuan yang benar dalam kehidupan orang percaya (Roma 14:8). ${ }^{31}$ Menyangkal diri merupakan satu pedoman untuk mengikuti teladan Kristus dan menjadi serupa dengan Dia.

\section{Memikul Salib}

Salib menjadi lambang kesatuan orang percaya dengan Kristus, bukan hanya karena mengikuti teladanNya tetapi karena apa yang telah Ia lakukan dalam kematianNya sebagai pengganti di kayu salib. Itu sebabnya dalam kehidupan spiritualitas orang percaya hendaknya menjadikan Kristus sebagai teladan. Bagi Calvin, orang percaya harus meniru Kristus sebagai teladan dalam arti kehidupannya selaras dengan pola kehidupan Kristus, bukan hanya sebagai suatu hasil karya batiniah di dalam hati tetapi juga sebagai hasil pemeliharaan Allah atas situasi kehidupan orang percaya khususnya kesulitan dan penderitaan yang menjadi bagian dari hidup orang percaya. ${ }^{32}$ Sekalipun memikul salib adalah penderitaan namun membawa orang percaya dalam kesempurnaan dengan Kristus dan menghancurkan kesombongan serta memampukan orang percaya untuk mengalihkan keyakinan pada diri sendiri kepada Allah. Artinya salib bukan hanya mengenai penderitaan tetapi sukacita terbesar dibalik penderitaan itu, yakni melalui salib Allah menyediakan keselamatan bagi orang percaya.

\section{Bertekun dalam Doa}

Bertekun dalam doa merupakan aspek spiritualitas yang penting dalam kehidupan orang percaya dimana Pengenalan akan Allah hendaknya membawa manusia untuk

30 McNeill, Calvin: Institutes of the Christian Religion, 689-690.

31 Yohanes Calvin, Institutio: Pengajaran Agama Kristen, 122-123; McNeill, Calvin: Institutes of the Christian Religion, 690.

32 Wallace, Calvin's Doctrine of the Christian Life, 47. 
hidup takut akan Allah dan mempermuliakan Allah. ${ }^{33}$ Sikap takut akan Allah salah satunya diwujudnyatakan dalam kehidupan yang bertekun di dalam doa. Menurut Calvin definisi doa adalah:

Prayer is none other than an expanding of or heart in the presence of God when we pray, we do no other than pour out thoughts and wished before God. Prayer is this kind of conversation between men and God, by which they yam entrance into the heavenly sanctuary and personally address Him on the strength of his promises, with the results that in their distresses they see that they have not vainly believed His word alone. ${ }^{34}$

Doa menunjukkan ketidakmampuan manusia tanpa Allah karena itu manusia merindukan untuk berada di dalam Allah. ${ }^{35}$ Artinya manusia bergantung mutlak kepada Allah.

\section{Tujuan Spiritualitas menurut Yohanes Calvin}

Menjadi Serupa dengan Kristus

Menurut Calvin, orang percaya yang telah menyerahkan dirinya kepada Allah dengan sendirinya akan menjadikan Kristus sebagai teladan hidupnya yang terwujud dalam sikap hidup tiap-tiap hari. ${ }^{36}$ Wallace menegaskan bahwa hal yang penting bagi Calvin dalam konsepnya mengenai spiritualitas adalah bagaimana kehidupan Kristen diubahkan untuk menjadi serupa dengan Kristus, hidup berpadanan dengan Kristus, karena hanya melalui Kristus didapatkan kesempurnaan rupa Allah Bapa. ${ }^{37}$ Orang percaya yang ingin menjadi serupa dengan Kristus hendaknya menempatkan Kristus sebagai otortas tertinggi dalam hidupnya. Dengan demikian tujuan spiritualitas adalah untuk menjadi serupa seperti Kristus, baik hati, pikiran, sikap dan seluruh hidupnya meneladani Kristus.

\section{Memuliakan Allah}

Salah satu tujuan utama dalam kehidupan spiritualitas adalah memuliakan Allah. Kebergantungan mutlak manusia pada Allah hendaknya mengikat orang percaya untuk terus memuliakan Allah karena ini merupakan tugas orang percaya. Memuliakan Allah adalah kehendak Allah sendiri dan manusia sebagai makhluk spiritual yang diciptakan Allah hendaknya menyadari bahwa jika Allah sebagai pemilik otoritas tertinggi dalam hidupnya maka itu berarti orang percaya harus melakukan kehendak Allah dengan tujuan untuk memuliakan Allah (Institutio III.vii.2). Reformasi bukan hanya bertujuan

33 Dankbaar, Calvin, Djalan Hidup Dan Karjanya, 153-154.

${ }^{34}$ Wilhelm Niesel, The Theology of Calvin, ed. Harold Knight (Michigan: Baker Book House, 1980), 152.

35 Ibid, 850.

${ }^{36}$ Yohanes Calvin, Institutio: Pengajaran Agama Kristen, 120.

37 Wallace, Calvin's Doctrine of the Christian Life, 107-108. 
untuk menghasilkan suatu theologia yang benar, tetapi juga untuk menghasilkan ibadah yang benar karena tujuan eksistensi manusia adalah untuk mengenal Allah dan memuliakan Allah melalui ibadah dan ketaatan. ${ }^{38}$ Dengan demikian memuliakan Allah dapat dilakukan dengan pujian dan penyembahan kepada Allah yang di dalamnya terkandung penghormatan, pengagungan yang besar kepada Allah, Calvin menuliskan "that God is to be honored only according to his commands in Scripture." 39 Penghormatan dan pengagungan kepada Allah dilakukan berdasarkan perintah Allah di dalam Alkitab. memuliakan Allah juga berarti menanggapi atau meresponi penyataan kasih karunia Allah bagi orang percaya di mana Allah di dalam kehendakNya menyatakan diri pada manusia untuk memuliakan Allah.

\section{Implikasi Spiritualitas Calvin bagi Pendidikan Warga Gereja di Era New Normal}

Sumber penelitian lapangan adalah Jemaat Gereja Persekutuan Misi Injili Indonesia (GPMII) yang merupakan salah satu Gereja yang lahir dari Lembaga Misi Chinese Foreign Missionary Union (CFMU) selain Gereja Persekutuan Kristen (GEPEKRIS) dan Gereja Kebangunan Kalam Allah (GKKA). ${ }^{40}$ Sejarah berdirinya GPMII Balikpapan tidak dapat dilepaskan dari GPMII Samarinda yang merupakan tempat pertama lahirnya GPMII, didirikan oleh Pdt. Yason S. Liem pada tahun 1929. Bersama dengan orang Kristen Tiongkok, mereka menyewa rumah untuk dijadikan ruang ibadah dengan nama Gereja Hok Im Tong. Tahun 1972 CFMU mengubah nama menjadi Sinode Gereja Persekutuan Kristen dan GPMII Samarinda menjadi salah satu anggotanya. Agustus 1973 GPMII Samarinda mengangkat Chang Yong (ketua persiapan), Pdt. Matius Chou (penanggung jawab) dan beberapa anggota di antaranya $\mathrm{H}$. Cien Chou, kemudian dengan meminjam sebuah rumah mereka memulai kebaktian pertama di Balikpapan. Selanjutnya menyewa rumah untuk beribadah karena jumlah jemaat terus bertambah, kemudian GPMI Balikpapan dilayani oleh GI. Se Cin E dan GI. Yonatan Ie. ${ }^{41}$ Tahun 1976 GPMII Balikpapan dilayani oleh GI. Liaw In Sien alumni SAAT Malang dan sekalipun menghadapi banyak tantangan dalam proses pembangunan gedung gereja, tanggal 16 April 1980 GPMII diresmikan oleh Pdt. Matius Chou. ${ }^{42}$ Meskipun jumlah jemaat terus bertambah namun pemahaman mengenai kehidupan spiritualitas menjadi satu pergumulan bagi GPMII karena masih ada jemaat yang memiliki keterikatan yang kuat terhadap budaya atau tradisi etnis tertentu seperti: pai-pai. Dalam upaya menangani hal ini, GPMII mengadakan kelas pembinaan kerohanian, katekisasi, kelompok, seminar dan KKR dengan mengundang pembicara misalnya dari Lembaga Reformed Injili Indonesia

38 Carlos M. N. Eire, "John Calvin and the Church a Prism of Reform," in Calvin's Attack on Idolatry, ed. Timothy George (Kentucky: John Knox Press, 1990), 249.

39 Ibid, 252.

40 Ipin Alang and Feldi Endercun, "Sejarah Perkembangan 10 Tahun Terakhir 3 Sinode Ex-CFMU (1999-2009)" (Badan Kerjasama Tiga Sinode Ex-CFMU,GEPEKRIS, GKKA, GPMII, 2009), iv.

41 Ibid, 82-83.

42 Ibid, 82-83. 
(LRII). Jumlah responden 75 orang namun hanya 68 orang (laki-laki 33 orang dan perempuan 35 orang) yang mengisi angket dengan tingkat usia yang berbeda.

Berdasarkan analisa data yang ditemukan dilapangan maka implikasi bagi Pendidikan Warga Gereja di Era New Normal adalah sebagai berikut:

\section{Membangun Karakter}

Jemaat memiliki pemahaman bahwa spiritualitas adalah pengenalan akan Allah dalam hubungan yang intim dan kehidupan yang bergantung mutlak kepada Allah. Bagi Calvin, dasar hidup Kristen terletak pada kebenaran dimana Tuhan memerintahkan orang Kristen untuk hidup kudus dan Ia sendiri telah menyediakan penebusanNya melalui karya Kristus. ${ }^{43}$ Calvin mendasarkan pengajaran spiritualitas pada Allah bahwa Allah adalah sumber dan penentu dari spiritualitas itu sendiri. Menyangkal diri dan memikul salib serta bertekun dalam doa merupakan aspek spiritualitas yang menjadi bagian dalam mengikuti teladan Kristus dan untuk menjadi serupa dengan Kristus. Menyangkal diri menunjukkan bahwa jemaat tidak memiliki apapun atas dirinya, memikul salib adalah penderitaan yang dialami dalam mengikut Kristus, berhubungan erat namun berbeda dengan penderitaan Kristus. Melalui kehidupan yang bertekun dalam doa, jemaat menyadari ketidakmampuannya tanpa Allah sehingga mau tidak mau harus bergantung mutlak pada Allah. Spiritualitas membawa pengaruh yang besar dalam kehidupan keluarga yakni semakin mengasihi yang ditunjukkan dengan sikap bertanggung jawab serta menjadi berkat bagi keluarga. Artinya spiritualitas menurut Calvin yang didasarkan pada pengenalan akan Allah membangkitkan usaha jemaat dalam membangun karakter sehingga memiliki karakter yang berkualitas dan membawa dampak positif baik bagi diri sendiri maupun bagi orang lain.

\section{Melayani Tuhan}

Spiritualitas membawa untuk melayani Tuhan dan sesama sebagai gaya hidup dan menambah daya kreativitas dalam pelayanan. Bagi Calvin, hidup manusia hanyalah untuk melayani Allah, tidak hanya dengan kata-kata melainkan seluruh hidup harus dipersembahkan kepada Allah. ${ }^{44}$ Kesungguhan dalam melayani Tuhan yang dinyatakan dengan melayani sesama sementara penyembahan kepada Allah adalah hal yang utama termasuk hubungan dengan Allah dan itu diungkapkan dalam bagaimana orang percaya menjalani hidupnya dan bagaimana memperlakukan sesamanya. ${ }^{45}$ Spiritualitas memotivasi jemaat untuk melayani Tuhan, dinyatakan melalui melayani sesama dan

43 Richard G. Gamble, "Calvin and Sixteenth Century Spirituality: Comparasion with Anabaptist," Calvin Theological Journal (1996), 338.

${ }^{44}$ John H. Leith, John Calvin's Doctrine of the Christian Life (Lousville-Kentucky: Westminster, 1989), 43

\footnotetext{
45 Joel R. Beeke, “Calvin on Piety,” 145.
} 
berdampak pada hubungan sosial yang baik dengan sesama serta membentuk moralitas yang baik pula.

\section{Spiritualitas Yohanes Calvin dan motivasi dalam melayani Tuhan}

Kontribusi yang didapatkan dari spiritualitas menurut Calvin adalah membawa untuk melayani Tuhan dengan sungguh-sungguh disertai motivasi yang murni untuk melayani Tuhan dan bukan untuk kepentingan diri sendiri serta menjadi lebih maksimal dalam pelayanan. Motivasi yang murni berhubungan erat dengan pembentukan karakter seseorang yang dapat mempengaruhi pelayanannya. Untuk menghasilkan motivasi yang murni, diperlukan ketaatan sebagai sikap yang mutlak dari orang yang telah mengenal Allah. Dalam hal ini spiritualitas menurut Calvin menolong untuk belajar memiliki motivasi yang murni dalam pelayanan, dimana motivasi itu datang dari Allah sendiri yang telah menyelamatkan. Spiritualitas memurnikan motivasi dalam melayani Tuhan.

\section{Pola penerapan spiritualitas menurut Yohanes Calvin:}

Dalam menghadapi tantangan zaman yang semakin meluas secara khusus dengan berkembangnya kecerdasan spiritual dan berbagai kecerdasan lainnya sebagai bentuk kecerdasan tertinggi yang bertolak dari potensi diri manusia sehingga spiritualtas tidak selalu bersumber kepada Allah. Spiritualitas Calvin dapat disajikan sebagai materi seminar yang diadakan oleh lembaga gereja atau lembaga Kristen lainnya, dimana spiritualitas menurut Calvin menekankan pentingnya pengenalan akan Allah yang terwujud dalam kehidupan yang bergantung mutlak kepada Allah bukan kepada diri sendiri.

Spiritualitas menurut Calvin juga dapat disajikan sebagai materi diskusi dalam kelompok kecil, karena lebih memudahkan bagi jemaat untuk memahami inti dari kehidupan spiritualitas yang didasari oleh pengenalan akan Allah. Tidak menutup kemungkinan bahwa melalui diskusi dalam kelompok kecil ini pemahaman jemaat yang keliru mengenai spiritualitas dapat diubah sehingga dengan demikian jemaat dapat terus mengalami pertumbuhan spiritualitas.

\section{Langkah-langkah praktis kehidupan spiritualitas:}

Praksis spiritualitas dapat dilakukan melalui doa, ibadah dan tindakan kasih. Pertama, Doa merupakan persekutuan dengan Allah sekaligus menjadi penghubung dengan Allah, itu sebabnya melalui doa jemaat dapat dengan bebas menyatakan isi hati dan keriduannya kepada Allah namun demikian di dalam doa tetap ada unsur kerendahan hati untuk menerima apa yang Allah kehendaki bukan menerima berdasarkan kehendak diri sendiri.46 Doa menunjukkan ketidakmampuan manusia

${ }^{46}$ John Calvin, Commentaries on the First Epistle of Paul to the Thessalonians, terj. William Pringle (Michigan: Baker Book House, 1979), 297. 
tanpa Allah, karena itu manusia merindukan untuk berada di dalam Allah. ${ }^{47}$ Melalui doa, jemaat dapat memelihara dan membangun kehidupan spiritualitasnya sebagai wujud dari kesadaran kebergantungan pada Allah tiap-tiap hari.

Kedua, ibadah merupakan salah satu langkah praktis dalam kehidupan spiritualitas orang percaya yang telah mengenal Allah. menurut Calvin, tujuan eksistensi manusia adalah mengenal Allah dan memuliakan Dia melalui ibadah dan kepatuhan. Kedua hal ini tidak terpisahkan karena tidak mungkin seseorang sampai pada pengenalan akan Allah tanpa memberikan penyembahan kepada Dia. ${ }^{48}$ Ibadah kepada Allah mencakup relasi dengan sesama karena hubungan seseorang dengan Allah akan nyata melalui hubungan dengan orang lain. Ibadah bukan hanya dalam relasi dengan Allah saja, tetapi juga dalam relasi dengan sesama. Itu berarti ibadah merupakan salah satu sarana yang dapat digunakan oleh jemaat untuk memelihara kehidupan spiritualitas. Ketiga, kasih adalah perintah Allah yang utama bagi semua orang percaya bukan hanya kasih terhadap Allah tetapi juga terhadap sesama (Matius 22:37-40) itu sebabnya kasih sangat diperlukan dalam kehidupan spiritualitas. Semua manusia diciptakan menurut gambar Allah, ini merupakan fondasi dari semua pengajaran Calvin mengenai hubungan antar sesama. ${ }^{49}$ Kasih juga tidak lepas dari pengampunan, Allah sudah mengampuni, maka setiap orang percaya memiliki tanggung jawab yang sama untuk mengampuni sesamanya, sebagaimana Calvin menuliskan "it is that we remember not to consider men's evil intention but to look upon the image of God in them, which cancels and affaces their transgressions, and with its beauty and dignity allures us to love and embrance them."50 Melalui kasih, jemaat dapat terus membangun serta memelihara kehidupan spiritualitasnya dan mengalami pertumbuhan yang membawa ke arah keserupaan dengan Kristus sehinga menghasilkan kehidupan yang berbuah bagi Kristus dan membawa kemuliaan bagi Allah.

\section{KESIMPULAN}

Spiritualitas menurut Calvin membawa jemaat menyadari bahwa pengenalan akan Allah hendaknya menjadi dasar bagi pengalaman praktis dalam hidup tiap-tiap hari. Kesungguhan mengenal Allah berdampak pada karakter yang baik dan pelayanan yang dilakukan. Dengan kata lain jemaat menyadari bahwa melayani Tuhan yang dinyatakan dengan melayani sesama akan membawa dampak positif dalam membangun hubungan sosial serta membentuk moralitas yang baik pula. Hubungan sosial yang baik mengindikasikan hubungan yang baik dengan Allah. dalam semuanya ini peranan gereja juga sangat dibutuhkan karena menolong jemaat dalam menjalani proses pembentukan

\footnotetext{
47 McNeill, Calvin: Institutes of the Christian Religion, 850.

48 Eire, "John Calvin and the Church a Prism of Reform," 249.

49 Wallace, Calvin's Doctrine of the Christian Life, 150.

50 Ibid, 697.
} 
yang pada akhirnya menghasilkan karakter yang baik serta memberi dampak positif dalam pelayanan. Spiritualitas menurut Calvin ini dapat diterapkan sebagai materi seminar maupun dalam diskusi kelompok kecil sehingga pemahaman jemaat mengenai spiritualitas makin terbentuk. Adapun langkah praktis dalam membangun kehidupan spiritualitas, antara lain: doa, ibadah dan kasih.

\section{Referensi}

Alang, Ipin, and Feldi Endercun. "Sejarah Perkembangan 10 Tahun Terakhir 3 Sinode ExCFMU (1999-2009).” Badan Kerjasama Tiga Sinode Ex-CFMU,GEPEKRIS, GKKA, GPMII, 2009.

Berkhof, Louis. Teologi Sistematika 1: Doktrin Allah. Jakarta: LRII, 1993.

_——. Teologi Sistematika 5" Doktrin Gereja. Jakarta: LRII, 1997.

———. Teologia Sistematika 2: Doktrin Manusia. Jakarta: LRII, 1995.

Boettner, Loraine. Iman Reformed. Surabaya: Momentum, 2000.

Calvin, John. Commentaries on the First Epistle of Paul to the Thessalonians. editor William Pringle. Michigan: Baker Book House, 1979.

Chan, Simon. Spiritual Teologi. Yogyakarta: ANDI, 2002.

Dankbaar, W.F. Calvin, Djalan Hidup Dan Karjanya. Jakarta: BPK Gunung Mulia, 1967.

Eire, Carlos M. N. "John Calvin and the Church a Prism of Reform." dalam Calvin's Attack on Idolatry, edited by Timothy George. Kentucky: John Knox Press, 1990.

Gamble, Richard G. "Calvin and Sixteenth-Century Spirituality: Comparison with Anabaptist." Calvin Theological Journal (1996).

Joel R. Beeke. "Calvin on Piety." In The Cambridge Companion to John Calvin, editor Donald K. McKim. Cambridge: University Press, 2004.

Jonge, Christian de. Apa Itu Calvinisme? Jakarta: BPK Gunung Mulia, 2001.

Knitter, Paul F. Satu Bumi Banyak Agama. Jakarta: BPK Gunung Mulia, 2003.

Leith, John H. John Calvin's Doctrine of the Christian Life. Lousville-Kentucky: Westminster, 1989.

Lumintang, Stevri I. Theologia Dan Misiologia Reformed. Batu: Dept. Literatur YPPII, 2006.

Madjid, Nurcholis. "Kehampaan Spiritual Masyarakat Modern." dalam Agama Dan Kegalauan Masyarakat Modern. Jakarta: Mediacita, 2000.

McNeill, John T. Calvin: Institutes of the Christian Religion. Philadelphia: The Westminster Press, 1960.

Nazir, Mohammad. Metode Penelitian. Jakarta: Ghalia Indonesia, 1988.

Niesel, Wilhelm. The Theology of Calvin. Editor Harold Knight. Michigan: Baker Book House, 1980.

Shaw, Mark. Sepuluh Pemikiran Besar dari Sejarah Gereja. Surabaya: Momentum, 2003.

Tong, Stephen. Peta Dan Teladan Allah. Surabaya: Momentum, 1990. 
Wallace, Ronald S. Calvin's Doctrine of the Christian Life. Geneva: Divinity School Press, 1982.

Wendel, Francois. Calvin Origin and Development of His Religious Thought. Michigan: Baker Book House, 1997.

Yohanes Calvin. Institutio: Pengajaran Agama Kristen. Editor Arifin dan Th. van den End Winarsih, J.S. Aritonang. Jakarta: BPK Gunung Mulia, 2015. 